\title{
Isolation and preservation of Toxoplasma gondii
}

\author{
W. KWANTES, D. G. FLECK, AND R. A. PAYNE \\ From the Public Health Laboratory, Swansea
}

SYNOPSIS Thirteen isolations of Toxoplasma gondii were made from 110 specimens of various human tissues and tissue fluids. Twelve of these were from lymph nodes and one from a specimen of cerebrospinal fluid; all isolations were from cases with dye test titres of $1 / 512$ or more. A description of the deep freeze method used to preserve the $T$. gondii strains isolated is included. It is hoped that attempts at isolation of this organism will be made more frequently in future.

It cannot be stated too often that the only method of diagnosing an infection with Toxoplasma gondii with certainty is by isolation of the organism. As this protozoon is an obligate intracellular parasite isolation is difficult. The experience of the Toxoplasma Reference Laboratory for southern England and Wales in attempting to isolate the organism from suspected cases might therefore be of interest.

Whenever a strain was isolated we thought it necessary to store it so that comparisons could be made with other strains. Previous workers (Eyles, Coleman, and Cavanaugh, 1956; Chandler and Weinman, 1956) described methods of preservation which used glycerine at low temperature. In view of the widespread use of dimethyl sulphoxide as a constituent of the suspending medium for the preservation of tissue culture cells (Porterfield and AshwoodSmith, 1962; Dougherty, 1962) and trypanosomes (Walker and Ashwood-Smith, 1961) we used this material in preserving various strains of $T$. gondii. Such a method reduced the likelihood of bacterial contamination which may occur with serial passage in animals and also allowed comparisons of virulence to be made between strains isolated and kept frozen and those passaged many times in animals. It also lowered the risk of contamination of one strain of $T$. gondii with others of different characters.

\section{METHODS}

ISOLATION Tissues, other than products of conception, were sent to the laboratory by post, without cooling but with antibiotic saline (penicillin $100 \mu \mathrm{g} . / \mathrm{ml}$., streptomycin $100 \mu \mathrm{g} . / \mathrm{ml}$., in $0.9 \% \mathrm{NaCl}$.). Immediately on arrival each tissue was ground up in a small amount of antibiotic saline with a pestle and mortar. One $\mathrm{ml}$. of the tissue suspension was injected intraperitoneally into each of four mice whose serum had previously been found to be dye test negative. Every cage of inoculated mice contained an

Received for publication 14 December 1966. uninoculated control mouse but at no time did this control become infected with $T$. gondii. Eight weeks after inoculation, the mice were killed by gassing with coal gas, the brains removed and examined for $T$. gondii, and the heart blood was tested for dye test antibody. Some of the mice sickened soon after inoculation; these were killed and the brains and peritoneal fluid examined for $T$. gondii. Products of conception were collected from a nearby hospital, macerated in antibiotic saline and $1 \mathrm{ml}$. injected into each of 12 mice. After one week the mice were killed, the brains, livers, and spleens were pooled and injected intraperitoneally into three mice. This procedure was continued at weekly intervals for six weeks, the final three being examined in the manner previously described.

PRESERVATION When a strain of $T$. gondii was isolated a suspension of infected mouse brain was centrifuged at $1,500 \mathrm{~g}$ for 10 minutes and the supernatant fluid replaced with $10 \%$ dimethyl sulphoxide and $15 \%$ human serum (known to be free from dye test antibody) in Hanks balanced salt solution. One strain in particular, a cystic strain which we have designated the 'Lansdowne' strain, was investigated for infectivity before and after storage. This was also carried out with the R.H. strain which is in world wide use for the dye test.

STORAGE The material was stored in $2 \mathrm{ml}$. ampoules and slowly frozen at a rate of cooling of less than $1^{\circ} \mathrm{C}$. per minute. This was achieved by placing the ampoules in a special polystyrene container 4in. $\times 2$ in. $\times 2$ in. and cooling them in an insulated box about 6 in. $\times 6$ in. $\times 6$ in. containing a block of solid carbon dioxide. The polystyrene container was made from two pieces of polystyrene 4 in. $\times 2$ in. $\times 1$ in. held together with an elastic band. Each had a depression about 2 in. $\times 1$ in. $\times$ tin. deep which was made by heating a bijou bottle in a bunsen burner and pushing it sideways into the polystyrene until the required depression had been made. A simple method of checking the rate of cooling was to enclose a test ampoule of carbon tetrachloride which has a freezing point of $-22.9^{\circ} \mathrm{C}$. With a room temperature of about $20^{\circ} \mathrm{C}$. the ampoule should take between three-quarters of an hour to one hour to freeze. Obviously if it takes less 
time, more insulation is required and if it takes more, the depression in the polystyrene should be increased.

After slow cooling of the ampoules for two to four hours they were transferred to a specially made container for long-term storage. This consisted of a solid block of aluminium in the form of a disk 6 inin. diameter and $2 \mathrm{in}$. thick. It had 55 holes $\frac{1}{2}$ in. diameter and 13 in. deep drilled into one of its flat surfaces. Ampoules were stored in the holes and could be easily inserted, removed and located. The aluminium disk was kept cold by being in contact with the top of a block of solid carbon dioxide. Provided the metal was in direct contact with the solid carbon dioxide the temperature of the ampoules was well below $-70^{\circ} \mathrm{C}$. all the time. Even if the disk was removed for a minute or two for replenishing the carbon dioxide or removal or insertion of the ampoules, the temperature did not rise above $-70^{\circ} \mathrm{C}$. Temperature measurements to within $1^{\circ} \mathrm{C}$. were made by measuring the resistance of a type $F$ thermistor which had been calibrated in liquids with varying freezing points.

Frosting around the ampoules and upper part of the disk was prevented by means of polythene. The disk was put into a close-fitting polythene bag and string was tied firmly around its circumference which was grooved to avoid slipping. The bottom of the bag was subsequently cut away so that the base of the disk could be in direct contact with the solid carbon dioxide. Ampoules could be inserted and removed through the upper end of the bag which was normally kept closed with an elastic band during storage.

The solid carbon dioxide blocks manufactured by I.C.I. are rectangular and measure $7 \frac{1}{2}$ in. square by $10 \mathrm{in}$. long. A satisfactory box for storing the solid carbon dioxide and aluminium disk was made by sticking four pieces of 3 in. thick polystyrene, measuring 11 in. $\times 18$ in. onto a 3 in. thick square section, 14 in. $\times 14$ in., as a base. The top consisted of an upper 3 in. thick piece 14in. square stuck to a lin. thick piece $7 \frac{1}{2}$ in. square enabling it to be located. Figure 1 illustrates the construction of the polystyrene container.

A block of solid carbon dioxide would last five to six days but it was administratively convenient to receive and insert a fresh block regularly twice a week. Defrosting was carried out by periodically turning the polystyrene container upside down and giving it a sharp tap on its base to remove the frost which had formed.

RECONSTITUTION AND ESTIMATION OF SURVIVAL OF TOXOPLASMA After removal of the ampoules rapid

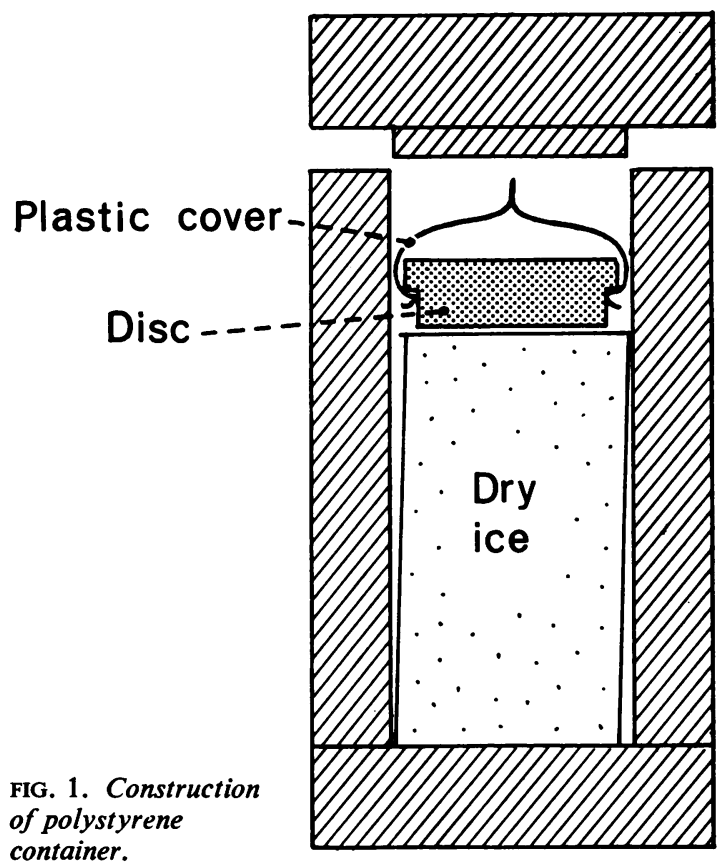

container.

thawing was found essential and this was accomplished by dropping them into water at $37^{\circ} \mathrm{C}$. They were centrifuged at $1,500 \mathrm{~g}$ for five minutes and after opening, the supernatant was removed and replaced with $1 \mathrm{ml}$. antibiotic saline. This was inoculated into two mice to determine whether the strain had survived. In the case of the Lansdowne strain serial tenfold dilutions were made, $0.5 \mathrm{ml}$. of each dilution inoculated into each of six mice, and after six weeks they were examined for cysts and antibody. In the case of the R.H. strain the mortality ratio after 21 days was determined.

For a comparison some ampoules containing toxoplasma were stored in liquid nitrogen but the survival ratio did not appear to be noticeably increased. An occasional ampoule exploded on thawing and this method of storage was discontinued because it was considered dangerous.

\section{RESULTS}

Table I shows the results of attempts at the isolation

TABLE I

ATTEMPTS AT ISOLATION OF T GONDII

\begin{tabular}{lcccc} 
Dye Test & $\begin{array}{l}\text { Lymph } \\
\text { Nodes }\end{array}$ & $\begin{array}{l}\text { Cerebro Spinal } \\
\text { Fluid }\end{array}$ & $\begin{array}{c}\text { Products of } \\
\text { Conception }\end{array}$ \\
\hline Negative & $0 / 5$ & $0 / 7$ & $0 / 8$ & $0 / 2$ \\
Positive $1 / 4-1 / 256$ & $0 / 11$ & $0 / 7$ & $0 / 4$ & $0 / 14$ \\
Positive $1 / 512$ or more & $12 / 26$ & $1 / 9$ & $0 / 1$ & $0 / 16$ \\
Total & $12 / 42$ & $1 / 23$ & $0 / 13$ & $13 / 52$
\end{tabular}

Each fraction $=$ No. of isolations $/$ No. of attempts

${ }^{1}$ Other = Tonsil (3), saliva (9), sputum (1), lung tissue (1), brain tissue (2), liver tissue (2), cardiac muscle (1), blood (4), Marrow (1), pleural fluid (1), pericardial fluid (2), ascitic fluid (1), menstrual fluid (3), eye fluid (1). 
of $T$. gondii from various human tissues. Of the 110 tissues examined, isolations were made from 13 $(12 \%)$. Apart from one isolation from a sample of cerebrospinal fluid the remainder were from lymph nodes and these were all from patients with a dye test titre of $1 / 512$ or more. The products of conception, which consisted mainly of placental tissue, were examined in the way described by Langer (1963) and were taken from patients who had had at least two previous abortions. Unlike Langer (1963), who isolated the parasite from placental tissue from two out of 11 women, we were unable to make a single isolation from 13 attempts. No isolations were made from specimens of tonsil, saliva, sputum, lung tissue, brain tissue, liver tissue, cardiac muscle, blood, marrow, pleural fluid, pericardial fluid, ascitic fluid, menstrual fluid, or the fluid from an eye.

Table II shows the estimation of the L.D.50 for the R.H. strain of $T$. gondii before and after preservation for three months by the described method. There is a $1 / 100$ survival rate similar to that obtained by Eyles et al. (1956) and by Chandler and Weinman (1956). No change in virulence was noted after passaging the R.H. strain following deep freezing. For the cystic Lansdowne strain a quantitative estimation of the survival of the strain was only approximate, as the control group inoculated with a mouse brain

TABLE II

ESTIMATION OF THE L.D. 50 FOR THE R.H. STRAIN OF T. GONDII

\begin{tabular}{|c|c|c|c|}
\hline \multicolumn{2}{|c|}{$\begin{array}{l}\text { Before Preservation in } \\
\text { Dimethyl-Sulphoxide }\end{array}$} & \multicolumn{2}{|c|}{$\begin{array}{l}\text { After Preservation in } \\
\text { Dimethyl-Sulphoxide }\end{array}$} \\
\hline Dilution $^{1}$ & $\begin{array}{l}\text { Mortality } \\
\text { Ratio after } \\
21 \text { Days }\end{array}$ & Dilution & $\begin{array}{l}\text { Mortality } \\
\text { Ratio After } \\
21 \text { Days }\end{array}$ \\
\hline $\begin{array}{l}10^{-1} \\
10^{-2} \\
10^{-3} \\
10^{-4} \\
10^{-5} \\
10^{-6} \\
\\
1 \text { concentr } \\
\text { suspensio } \\
\text { toxoplasn }\end{array}$ & $\begin{array}{c}6 / 6 \\
6 / 6 \\
6 / 6 \\
6 / 6 \\
3 / 6 \\
0 / 6 \\
\text { L.D. }=10^{-5} \\
\text { n of undiluted } \\
=15 \times 10^{6} \\
\text { ml. }\end{array}$ & $\begin{array}{l}10^{-1} \\
10^{-2} \\
10^{-3} \\
10^{-4} \\
10^{-5} \\
10^{-8}\end{array}$ & $\begin{array}{c}6 / 6 \\
6 / 6 \\
4 / 6 \\
0 / 6 \\
0 / 6 \\
0 / 6 \\
\text { L.D. } 50=10^{-3.26}\end{array}$ \\
\hline
\end{tabular}

suspension did not show an end point at the dilution $10^{-4}$ (Table III). Only the mice with cysts in their brains had positive dye tests and the survival rate after storage for three months was about $1 / 1,000$. Of the 13 strains isolated, 12 have been tested for viability after storage and all have survived. Two have survived for at least two years, 10 have survived for periods varying between six and 18 months, and the remaining strain, which has been stored for only a few weeks, has not yet been tested.

\section{DISCUSSION}

The R.H. strain of $T$. gondii was preserved for three months and its virulence remained unchanged. Several other strains were isolated (chiefly from lymph nodes) and were preserved in the same way; all produced cysts in mice and their virulence did not change with preservation or with serial passage.

Strains of $T$. gondii have been isolated in the past from lymph nodes (Lelong, Bernard, Desmonts, and Couvreur, 1960), tonsils (Siim, 1961), brain and cerebrospinal fluid (Sabin, 1941), and blood and saliva (Cathie, 1954). In this laboratory from 1960 to 1966 isolations were made only from cerebrospinal fluid and lymph nodes. The clinical signs and symptoms of the patients from whom isolations were made from lymph nodes were those of febrile lymphadenopathy and did not differ greatly from those described by Beverley and Beattie (1958). The patient from whom $T$. gondii was isolated from the cerebrospinal fluid was a case of congenital disease with encephalitis. No isolation was made from any gland taken at biopsy from a patient with a dye test titre below $1 / 512$. Our findings agree closely with those of Beverley and Beattie (1958) who adopted an arbitrary level of $1 / 256$ in the dye test as indicating active infection in glandular toxoplasmosis.

The failure to isolate toxoplasma from placental tissue from 13 patients with recurrent abortions does not support the results obtained by Langer (1963). He isolated the parasites from two out of 11 placental

TABLE III

ESTIMATION OF THE INFECTIVITY OF THE LANSDOWNE STAIN OF T. GONDII

Control Group

\begin{tabular}{lcl}
\hline \begin{tabular}{l} 
Before Preservation in Dimethyl Sulphoxide \\
\hline $\begin{array}{l}\text { Dilution of Mouse } \\
\text { Brain Suspension }\end{array}$
\end{tabular} & $\begin{array}{l}\text { Proportion of Mice } \\
\text { Showing Cysts }\end{array}$ & $\begin{array}{l}\text { Proportion of Mice } \\
\text { with Positive } \\
\text { Dye Tests }\end{array}$ \\
\hline $10^{-1}$ & $6 / 6$ & $6 / 6$ \\
$10^{-2}$ & $6 / 6$ & $6 / 6$ \\
$10^{-3}$ & $6 / 6$ & $6 / 6$ \\
$10^{-4}$ & $4 / 6$ & $4 / 6$
\end{tabular}

Test Group

\begin{tabular}{lll}
\hline \begin{tabular}{l} 
After Preservation in Dimethyl Sulphoxide \\
\hline $\begin{array}{l}\text { Dilution of Mouse } \\
\text { Brain Suspension }\end{array}$
\end{tabular} & $\begin{array}{l}\text { Proportion of Mice } \\
\text { Showing Cysts }\end{array}$ & $\begin{array}{l}\text { Proportion of Mice } \\
\text { with Positive } \\
\text { Dye Tests }\end{array}$ \\
\hline $10^{-1}$ & $5 / 6$ & $5 / 6$ \\
$10^{-2}$ & $0 / 6$ & $0 / 6$ \\
$10^{-3}$ & $0 / 6$ & $0 / 6$ \\
$10^{-4}$ & $0 / 6$ & $0 / 6$
\end{tabular}


tissues obtained from women with recurrent abortions, but also made isolations from brain tissue, abrasion material, lochia, foetal fluid, milk, and menstrual blood. His highest isolation rate, 11 from 28 attempts, was from brain tissue but unfortunately this material has so far not been available to us.

The isolation of toxoplasma from $12 \%$ of all specimens examined is sufficiently encouraging to suggest that more vigorous attempts be made in future.

Our thanks are due to the many pathologists in Wales and the south of England who sent material for isolation. Thanks are especially due to Dr. I. Pugh, Medical
Superintendent of the Hill House Isolation Hospital, for sending the material from cases of recurrent abortion.

\section{REFERENCES}

Beverley, J. K. A., and Beattie, C. P. (1958). Lancet, 2, 379.

Cathie, I. A. B. (1954). Ibid., 2, 115.

Chandler, A. H., and Weinman, D. (1956). Amer. J. clin. Path., 26, 323.

Dougherty, R. M. (1962). Nature (Lond.), 193, 550.

Eyles, D. E., Coleman, M., and Cavanaugh, D. J. (1956). J. Parasit. 42, 408.

Langer, H. (1963). Obstet. and Gynec., 21, 318.

Lelong, M., Bernard J., Desmonts, G., and Couvreur, J. (1960). Arch. franç. Pédiat., 17, 281.

Porterfield, J. S., and Ashwood-Smith, M. J. (1962). Nature (Lond.), $193,548$.

Sabin, A. B. (1941). J. Amer. med. Ass., 116, 801.

Siim, J. C. (1961). Surv. Ophthal., 6, 781.

Walker, P. J., and Ashwood-Smith, M. J. (1961). Ann. trop. Med. Parasit., 55, 93.

\section{The March 1967 Issue}

Broadsheets and symposia

Peripatetic patients and pathologists AIR VICE- MARSHAL W. P. STAMM

Histological features of the nephrotic syndrome associated with quartan malaria J. w. KIBUKAMUSOKE and M. S.R. HUTT

Chromoblastomycosis (possibly Cladosporium) of the breast in an English woman L. HENRY and A. P. ROSS

Basaloid carcinoma of the anal canal LILLIAN S. C. PANG and B. C. MORSON

Adenocarcinoma of the pyloric antrum with extensive squamous differentiation $\mathrm{K}$. J. DONALD

Fibrous bands in conducting pulmonary arteries M. TESSA MORRELL, and M. S. DUNNILL

A critical and comparative study of methods of isolating tumour cells from the blood J. A. FLEMING and J. W. STEWART

Hypofibrinogenaemia in metastatic carcinoma of the prostate: suppression of systemic fibrinolysis by heparin P. W. STRAUB, G. RIEDLER, and P. G. FRICK

Benign familial polycythaemia C. G. GEARY, H. E. AMOS, and J. E. MACIVER

Autoantibodies reacting with heart muscle tissue in coronary heart disease I. STRAUSZ and GY. DóBIÁs

Screening lead workers for the presence of stippled erythrocytes R. L. CLARK, J. H. JONES, and J. F. JONES

Use of Sephadex column chromatography in the assessment of thyroid status T. M. D. GIMLETTE

Comparison of three simple methods for the assessment of 'free' thyroid hormone T. M. D. GIMLETTE
Diagnostic value of liver function tests and Entamoeba histolytica antibody studies in East Africans D. P. MULLAN, A. M. WARD, S. SHAH, and A. L. JEANES

Regulations of intestinal alkaline phosphatase levels in the rat w. C. WATSON, ELSPETH S. MURRAY, and MARY D. GARDNER

Biological findings in Von Willebrand's pedigrees: implications for inheritance DOMINIQUE MEYER, MARIEJOSÉ LARRIEU, PIERRE MAROTEAUX, and JACQURS P. CAEN

Wound infections acquired from a disperser of an unusual strain of Staphylococcus aureus G. A. J. AYLIFFE and B. J. COLLINS

Diagnosis and treatment of infection with Brucella abortus biotype 5 L. ROBERTSON

A system of screening for the presence of a number of common drugs MERLE DUNLOP and D. H. CURNOW

\section{Technical methods}

Multichannel system for the automatic recording of clot lysis J. D. CASH and E. LEASK

Determination of methaemalbumin in plasma G. C. CHONG and J. A. OWEN

Rapid method for the preparation of replicate microslide tissue cultures to facilitate immunofluorescent identification of unknown virus isolates R. G. SOMMERVILLE

Improved optical equipment for immunofluorescence studies O. M. LIDWEEL, C. E. D. TAYLOR, S. P. CLARK, and G. V. HEIMER

Use of barium sulphate as a continuous market for faeces MATTHEW DICK

Letters to the Editor

Book reviews

Copies are still available and may be obtained from the PUBLISHING MANAGER, BRITISH MEDICAL ASSOCIATION, TAVISTOCK SQUARE, W. c. 1, price 18s. 6D. 